\title{
The Adoption of a Standard Definition of Cultural Heritage
}

\author{
Damna A. Alzahrani
}

\begin{abstract}
International law plays an important role in improving global governance. International heritage law, however, has received much less attention than other areas of international law. Protecting heritage is vital as it facilitates understanding about the culture and the people of different places. It can also provide a clearer appreciation of the rich history of civilizations on Earth. As part of the United Nations, UNESCO has the most significant part to play in the protection of such heritage and it is responsible for a number of heritage treaties. There are two international instruments in cultural heritage protection that are interrelated in their attempts to develop a coherent international legal framework for the protection of cultural heritage. The Convention Concerning the Protection of the World Cultural and Natural Heritage complemented by the Convention for the Safeguarding of the Intangible Cultural Heritage which in 2003 attempted to improve upon the deficiencies in the coverage of the World Heritage Convention. This paper will analyze a standard definition of cultural heritage to facilitate a uniform understanding of the nature of its subject matter and the development of a coherent international legal framework for its protection.
\end{abstract}

Index Terms-Convention, cultural, heritage, framework, protection, safeguarding, intangible.

\section{INTRODUCTION}

The Convention for the Protection of World Cultural and Natural Heritage in 1972 (World Heritage Convention) was the first attempt by the United Nations to establish a coherent framework for protection of these resources [1]. However, this Convention failed to recognize the intangible qualities of human culture. 30 years later, the Convention for the Safeguarding of the Intangible Cultural Heritage in 2003 attempted to improve upon the deficiencies of the World Heritage Convention [2]. This paper reveals numerous issues associated with the diverse range of definitions of cultural heritage and opinions regarding the manner in which it should be protected, particularly in the case of the cultural heritage of indigenous peoples. Who gets to decide what valuable cultural heritage is? What if indigenous peoples no longer want to protect their heritage because of modernizing influences? These problems represent barriers to the protection of cultural heritage, though of course even the existence of a coherent international framework would not ensure its protection as such a regime would be likely to

Manuscript received September 14, 2012; revised November 27, 2012 This work is a part of my Phd research sponsored by the King Abdullah Scholarship Program.

Damna A. Alzahrani is with the University of Western, Australia, Faculty of Law, Perth, Western Australia (e-mail:damnaz@hotmail.com). experience the same problems of enforcement that plague other realms of international law.

\section{WORLD HERITAGE CONVENTION}

Beginning in the 1970s, and leading up to the adoption of the Convention for the Safeguarding of the Intangible Cultural Heritage in 2003, the United Nations Education and Scientific Organization UNESCO had a team of experts who worked on protecting cultural heritage. The WHC was adopted early but it was recognized that it did not cover all cultural heritage. UNESCO filled some of the gaps with the UNESCO Convention on moveable property but that still left intangible heritage unprotected at the global level [3].

The World Heritage Convention identified two areas for specific definition: cultural heritage and natural heritage [4]. Only cultural heritage will be examined in this analysis. Cultural heritage consisted of the following as set out in article 1.

"Monuments: architectural works, works of monumental sculpture and painting, elements or structures of an archaeological nature, inscriptions, cave dwellings and combinations of features, which are of outstanding universal value from the point of view of history, art or science; Groups of buildings: groups of separate or connected buildings which, because of their architecture, their homogeneity or their place in the landscape, are of outstanding universal value from the point of view of history, art or science;

Sites: works of man or the combined works of nature and man, and areas including archaeological sites which are of outstanding universal value from the historical, aesthetic, ethnological or anthropological point of view" [1]. Essentially, this definition protects the products of human creation and engineering.

An analysis of this definition of cultural heritage reveals several key problems. Specifically, the words "outstanding universal value" subjects this definition to considerable range of opinion about how this standard should be defined. These are subjective words that are highly vulnerable to differences of opinion. Some experts, for example, might consider any cave drawing of outstanding universal value, while others might consider some more valuable than others. If there are differences of degree in the value of cultural heritage, then governments or industry interests that want to avoid protective laws against development around a cultural heritage site will seek to devalue these sites as less than "outstanding universal value."

To illustrate, imagine the discovery of a single cave drawing of a single animal in a region that has been selected by tourism developers for a resort. Archeologists and other 
defenders of a broad definition of cultural heritage might certainly want to protect this area for further exploration, and this will lead them to conclude that this single cave drawing represents cultural heritage of "outstanding universal value." However, in comparison to other sites with numerous cave drawings that are more elaborate and detailed, this site with a single cave drawing might be deemed less than "outstanding universal value." Indeed, the word "outstanding" implies that not all sites with cultural heritage deserve to be protected. Some sites with cultural heritage must be less than "outstanding" based on this definition and thus unworthy of protection under an international legal framework. The Operational Guidelines provide assistance in determining what outstanding universal value means [11].

Another problem with the definition of the World Heritage Convention is that it does not apply to movable tangible property [3]. Thus, the concerns about trafficking of cultural heritage goods were not addressed under this Convention. Ultimately, this omission meant that a cultural heritage site could be stripped of any remnant of cultural heritage that could be removed, and only the structures of the site would remain.

In addition, the World Heritage Convention failed to protect intangible cultural heritage. Indeed, the World Heritage List included mostly sites from industrialized nations, reflecting the long history of architectural advancement compared to developing nations [3]. In developing nations, folklore and oral tradition are more common, and these forms of intangible cultural heritage were neglected by the World Heritage Convention.

\section{CONVENTION FOR THE SAFEgUARDING OF THE INTANGIBLE CULTURAL HERITAGE}

Given the difficulties of providing broad protection for all types and forms of cultural heritage, one could imagine how developing coherent definitions of intangible cultural heritage might pose an even greater difficulty. Intangible cultural heritage exists without physical references, and this makes it even more difficult to identify, define and evaluate for the level of protection it deserves. The Convention for the Safeguarding of the Intangible Cultural Heritage (ICH Convention) attempted to address the omission of intangible cultural heritage in the World Heritage Convention [3].

One of the interesting issues that emerges in intangible culture is that it exists within a contemporary cultural practice. Intangible culture is not a monument or relic of the ancient past that exists only as a physical reminder of that cultural history. Intangible culture, since it exists independent of physicality, must necessarily exist in human practice, through language, music, customs and other activities of contemporary peoples. Thus, the ICH Convention (in Article 1(a)) seeks to "ensure respect for the intangible cultural heritage of communities, groups and individuals" [2]. This means that the cultures that exhibit intangible heritage elements must be kept alive and sheltered from economic development, resource utilization and other threats from the modern world.

One of the most important aspects of the definition of intangible cultural heritage is the ability of peoples from these cultures to determine what is deserving of protection. Intangible culture is what "communities, groups and, in some cases, individuals recognize as part of their heritage."[8]-[10] There are restrictions, however, to allowing communities and individuals who claim intangible culture to assert that this culture should be protected by an international legal framework at all costs. These limitations are based on international norms of human rights, environmental protection, and tolerance. In other words, a tribe that practices female genital mutilation should not be able to claim this practice as protected intangible culture.

The ICH Convention defines intangible cultural heritage in Article 2 as including:

1) The "intangible cultural heritage" means the practices, representations, expressions, knowledge, skills - as well as the instruments, objects, artefacts and cultural spaces associated therewith - that communities, groups and, in some cases, individuals recognize as part of their cultural heritage. This intangible cultural heritage, transmitted from generation to generation, is constantly recreated by communities and groups in response to their environment, their interaction with nature and their history, and provides them with a sense of identity and continuity, thus promoting respect for cultural diversity and human creativity. For the purposes of this Convention, consideration will be given solely to such intangible cultural heritage as is compatible with existing international human rights instruments, as well as with the requirements of mutual respect among communities, groups and individuals, and of sustainable development.

2) The "intangible cultural heritage", as defined in paragraph 1 above, is manifested inter alia in the following domains:

- Oral traditions and expressions, including language as a vehicle of the intangible Cultural heritage;

- Performing arts;

- Social practices, rituals and festive events;

- Knowledge and practices concerning nature and the universe;

- Traditional craftsmanship"[2].

One of the problems identified with the ICH Convention definition of intangible cultural heritage is the lack of "an illustrative list of elements." [3] Instead, the ICH Convention uses broader definitions that are more subject to interpretation. However, other scholars have come to different conclusions as to whether the ICH Convention's definition of intangible culture is adequate to protect such culture [8]. The ICH Convention used the term "intangible cultural heritage" to replace the list of items that was formerly used to describe such elements, including "folklore, traditional culture, oral heritage, and popular culture" [4]. These items were complicated by different ideas about how they themselves should be defined. Thus, in the ICH Convention, the term "intangible cultural heritage" was an attempt to find agreement on what should be protected.

The primary shift in the ICH Convention and its development of the term "intangible cultural heritage" was the emphasis that "intangible culture was, foremost, living heritage as itself practiced and expressed by members of 
cultural communities" [4]. This means that intangible culture cannot be a song, for example, that has been recorded by an anthropologist decades ago but is no longer sung by any of the living descendents of that culture. "ICH cannot retain its designation as such if it is appropriated by others who are not members of that community" [4].

According to Kurin's interpretation, this idea of intangible cultural heritage is more expansive and likely to protect more heritage than would occur if there was simply an illustrative list of elements, as Kuruk seems to suggest is ideal. Under former definitions of intangible culture, protection of this culture consisted of recording, documenting and preserving these elements outside of the culture in which they were practiced. For example, protection of intangible culture by UNESCO before the ICH Convention was manifested in a scholarly activity that sent a specialist to identify, define, document and preserve the cultural artifact. By contrast, the ICH Convention "shifts both the measure and the onus of safeguarding work to the cultural community itself. ICH is not preserved in states' archives or national museums"[4].

\section{Who Should Decide? What is Valuable?}

However, although Kurin does not raise this issue, a legitimate question concerns the wisdom of allowing communities to protect their culture, whether tangible or intangible. There might be many situations where such intangible culture is dying off due to pressures from the modern industrial world. For example, indigenous peoples might face a loss of youth who move to the urban areas to find work. Their language, rituals and practices might be dying off with the older members of the tribe. Moreover, tribal leaders might be interested in economic development that introduces modern lifestyles into the group, replacing intangible cultural practices. Thus, there might be some cases where decisions made by indigenous peoples themselves, as a result of external pressures, lead to the demise of intangible culture. In such cases, the work of scholars and other outsiders to protect intangible culture might be necessary because the indigenous peoples themselves are unwilling or unable to perform this function. In such a case, should the international legal framework simply allow the demise and loss of such intangible culture? Should intangible culture only be preserved if the members of that community are willing and able to preserve it?

Indeed, economic interests might seek to influence an indigenous peoples' practice of intangible culture and the value upon which those people place their intangible culture. For example, imagine an oil company that seeks to explore for resources in the Amazon rainforest. In order to win tribal agreements to search in their areas, the oil company offers cash or other material rewards to tribal leaders. These material rewards could lead tribal leaders to agree to oil exploration and operations on their lands, resulting in the loss of traditional lifestyles as tribal members are relocated. Material rewards in return for the use of tribal lands might end subsistence forms of survival, such as hunting, and the adoption of a cash economy.

Is such an indigenous culture truly making a decision to end their use of cultural heritage on their own, or is this the result of undue external pressures? Should indigenous peoples have the right to abandon such culture if they believe their lives could improve by modernizing? These are not simple questions to answer. In fact, in many cases, intangible culture might be more valued by scholars than it is by the indigenous peoples themselves, particularly if their old ways of life leave them impoverished.

Such pressures might certainly change such peoples' definition of what constitutes valued heritage. If intangible cultural heritage is living heritage, then one would expect that it would evolve based on internal and external forces. This suggests that generational changes might emerge in indigenous peoples about what intangible culture should actually be preserved and what is relevant to contemporary needs. "In fact, the definition of what constitutes heritage is an individual, subjective matter that depends on a person's background, life experiences, and personality." [5] How can definitions and lists of protected intangible culture be established by international legal frameworks if living heritage is constantly evolving and being reconsidered by members of the culture?

Indeed, the entire construction of legal frameworks established by modern scholars and experts from outside these indigenous cultures creates a barrier to properly protecting the cultural heritage of indigenous peoples. This entire process is biased in favor of the modern world, according to some scholars and activists. This is a paternalistic approach that seeks to protect what is seen as 'inferior and weaker' indigenous peoples. Moreover, this approach values indigenous cultures only in what they can provide to an understanding of human nature and experience, not the value that they provide to indigenous cultures themselves. As one commentator points out "in fact, most international and Australian law and public policy which purportedly seeks to protect indigenous Australians is based, in my view, on a belief that the value of Indigenous cultures is fundamentally instrumental" [6] According to this perspective, expressed by activist and legal scholar Nigel Stobbs of Queensland University of Technology, international frameworks should leave the issue of deserving protection to the cultures themselves, not base it on an estimation by outsiders of the value of those cultures to some notion of universal human value. However, Stobbs fails to reflect upon the scenarios in which indigenous peoples themselves might seek to devalue the protection of their cultural heritage as they seek modernization or economic development to improve their quality of life, whether real or perceived.

\section{Are Legal Frame Works InHEREnTLy BiASED AgAinst INDIGENOUS PEOPLES?}

The fact that legal definitions and frameworks are the basis of discussion about protection of cultural heritage, particularly the cultural heritage of indigenous peoples who lack understanding and use of Western law, raises inherent problems about fairness. Even though the ICH Convention, for example, attempts to define intangible cultural heritage as living heritage, it uses a system of definitions and frameworks that are unknown to most indigenous peoples. 
"Thus, in any discussion of the 'categories' of indigenous people's heritage and the environment there needs to be awareness that these legal frameworks are only one way of imagining the real: of deciding what is valuable, what is heritage."[7] Western law restricts rather than expands the idea of what heritage is and what heritage should be protected. This is particularly true of intangible culture. By creating definitions and frameworks for intangible culture, Western legal approaches create a tangible cultural history through its function in giving particular manifestation to choices about occupation and use of the environment."[7]

One solution to this problem is to stop delineating between natural and cultural heritage, and to include native peoples in the decision making process about what should be protected. [7] Under this holistic approach, the legal definitions and frameworks will become much more expansive and protective. Environmental conservation will be considered essential to cultural heritage protection, since modes of survival are intrinsically linked to rituals, customs, beliefs and practices. Due to the threat of external forces, primarily industrial development, liaisons between the indigenous peoples and the modern world are necessary.

\section{CONCLUSION}

The issue of cultural heritage, particularly intangible culture of indigenous peoples, raises issues of self-determination. The Declaration on the Rights of Indigenous Peoples affirms the right to safeguard and practice cultural heritage [12]. But should indigenous peoples have the right to abandon their cultural heritage based on their decisions about quality of life improvement through modernization?

The answer is definitely affirmative, and this ultimately means that the international legal frameworks to protect cultural heritage are limited by the self-determination of indigenous peoples themselves. Thus, there must be a component of the international legal framework that allows scholars and other experts to identify, document and preserve cultural heritage before it is entirely abandoned, whether willingly or unwillingly, by indigenous peoples. Idealistic notions about living heritage being wholly protected by indigenous peoples may paradoxically lead to the disappearance of this cultural heritage. International law to protect cultural heritage must provide the ability for indigenous peoples to continue living their heritage, but it must also prepare for the possibility that this heritage is constantly evolving into new forms, particularly under the pressure of modernization. A record must be kept of this living heritage as it evolves into new and different forms over time, and the international framework should not be hesitant to recognize that outsider experts and scholars are best equipped to conduct this effort in the interests of the developed world.

\section{REFERENCES}

[1] Convention for the Protection of the World Cultural and Natural Heritage, adopted by the General Conference at its seventeenth session. [Online]. Available: http://whc.unesco.org/archive/convention-en.pdf.

[2] International Convention for the Safeguarding of the Intangible Cultural Heritage. [Online]. Available: http://www.unesco.org/culture/ich/index.php

[3] P. Kuruk, "Cultural Heritage, Traditional Knowledge and Indigenous Rights - An Analysis of the Convention for the Safeguarding of intangible Cultural Heritage," Macquarie Journal of International and Comparative Environmental Law, vol. 1, no. 1, pp. 111-134, 2004.

[4] R. Kurin, "Safeguarding Intangible Cultural Heritage in the 2003 UNESCO Convention: A Critical Appraisal," Museum International, vol. 56, pp. 66-76.

[5] G. Aplin "The Nature of Heritage" Heritage - Identification, Conservation and Management, Oxford Uni Press, Melbourne, 2002, pp.13-27.

[6] N. Stobbs, "What Can We Do for You?" Indigenous Law Bulletin, vol. 6 , no. 9 , pp. 9 .

[7] L. Godden "Indigenous Heritage and the Environment," Environmental and Planning Law Journal, vol. 19, no. 4, pp. 260, 2002.

[8] J. H. Merryman, "Protection of the Cultural Heritage?" 38 American Journal of International Law, pp. 522, 1990.

[9] A. G. Aldape, "The International Protection of Cultural Property" Proceedings of the 7 Ist annual Meeting of the American Society of International Law, pp. 196- 207, 1977.

[10] L. K. Antonio, "The current status of international art law" 10 Suffolk Transnational Law Journal, pp. 51-8, 1986.

[11] UNESCO. Operational Guidelines for the Implementation of the World Heritage Convention. [Online]. Available: http://whc.unesco.org/archive/opguide08-en.pdf

[12] United Nations Declaration on the Rights of Indigenous Peoples art. [Online]. Available: http://iwgia.synkron.com/graphics/Synkron-

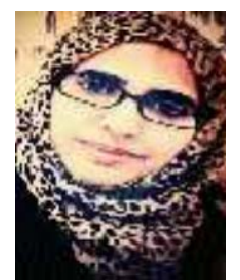

Damna A. Alzahrani is with the University of Western, Australia, Faculty of Law, Perth, WA, Australia. Thesis Topic: Heritage, Conservation and Good Governance. Damna holds a Master Degree in, International Environmental Law2011 from Macquarie University, Sydney, Australia. She holds another Master degree in History 2009 from King Abdulaziz University, Jeddah, Saudi Arabia. She Granted a Scholarship from King Abdullah Scholarship Program through Saudi Ministry of Higher Education to study at The University of Western Australia, Faculty of Law, Perth, Western Australia. Publications: D. Alzahrani, 'Heritage, Conservation and Good Governance. Heritage Issues in Saudi Arabia', 3rd International Conference on Heritage and Sustainable Development, Porto, Portugal UNESCO World Heritage Site, June 2012. D. Alzahrani, 'The protection of American Indian Intangible cultural heritage', Murdoch University Law Review. Coming soon in Vol. 19, No 2 (2012). 